\title{
Quick and improved immune responses to inactivated H9N2 avian influenza vaccine by purified active fraction of Albizia julibrissin saponins
}

\author{
Hongxiang Sun ${ }^{*}$ (D), Liyan Fei, Binnian Zhu and Minghua Shi
}

\begin{abstract}
Background: H9N2 Low pathogenic avian influenza virus (LPAIV) raises public health concerns and its eradication in poultry becomes even more important in preventing influenza. AJSAF is a purified active saponin fraction from the stem bark of Albizzia julibrissin. In this study, AJSAF was evaluated for the adjuvant potentials on immune responses to inactivated H9N2 avian influenza virus vaccine (IH9V) in mice and chicken in comparison with commercially oil-adjuvant.
\end{abstract}

Results: AJSAF significantly induced faster and higher $\mathrm{H} 9$ subtype avian influenza virus antigen (H9-Ag)-specific IgG, IgG1, IgG2a and IgG2b antibody titers in mice and haemagglutination inhibition (HI) and IgY antibody levels in chicken immunized with IH9V. AJSAF also markedly promoted Con A-, LPS- and H9-Ag-stimulated splenocyte proliferation and natural killer cell activity. Furthermore, AJSAF significantly induced the production of both Th1 (IL-2 and IFN- $\gamma$ ) and Th2 (IL-10) cytokines, and up-regulated the mRNA expression levels of Th1 and Th2 cytokines and transcription factors in splenocytes from the IH9V-immunized mice. Although oil-formulated inactivated H9N2 avian influenza vaccine ( $\mathrm{CH} 9 \mathrm{~V}$ ) also elicited higher $\mathrm{H} 9$-Ag-specific $\operatorname{lgG}$ and $\operatorname{lgG} 1$ in mice and $\mathrm{HI}$ antibody titer in chicken, this robust humoral response was later produced. Moreover, serum IgG2a and IgG2b antibody titers in CH9Vimmunized mice were significantly lower than those of $\mathrm{H} 9 \mathrm{~V}$ alone group.

Conclusions: AJSAF could improve antigen-specific humoral and cellular immune responses, and simultaneously trigger a Th1/Th2 response to IH9V. AJSAF might be a safe and efficacious adjuvant candidate for H9N2 avian influenza vaccine.

Keywords: Albizia julibrissin saponin, Adjuvant, H9N2 avian influenza vaccine, Immune response

\section{Background}

H9N2 Low pathogenic avian influenza viruses (LPAIV) have been prevalent in multiple avian species worldwide [1-3], which has resulted in the tangible economic losses in poultry [4-6]. More importantly, H9N2 LPAIV from poultry has been reported to have human virus-like

\footnotetext{
* Correspondence: sunhx@zju.edu.cn

Key Laboratory of Animal Virology of Ministry of Agriculture, College of Animal Sciences, Zhejiang University, Hangzhou 310058, China
}

receptor specificity [7], resulting in public health concerns about the increase in pandemic potential in human [8-10]. The phylogenetic analysis of H7N9 influenza avian virus causing human respiratory infections revealed its six internal genes from chicken H9N2 LPAIV $[11,12]$. H9N2 LPAIV was also proved to be the gene donor for H7N9 and H10N8 viruses infecting humans [13]. Recently, some cases of human infection with H9N2 LPAIV in China have been successively reported

C C The Author(s). 2020 Open Access This article is licensed under a Creative Commons Attribution 4.0 International License, which permits use, sharing, adaptation, distribution and reproduction in any medium or format, as long as you give appropriate credit to the original author(s) and the source, provide a link to the Creative Commons licence, and indicate if changes were made. The images or other third party material in this article are included in the article's Creative Commons licence, unless indicated otherwise in a credit line to the material. If material is not included in the article's Creative Commons licence and your intended use is not permitted by statutory regulation or exceeds the permitted use, you will need to obtain permission directly from the copyright holder. To view a copy of this licence, visit http://creativecommons.org/licenses/by/4.0/ The Creative Commons Public Domain Dedication waiver (http://creativecommons.org/publicdomain/zero/1.0/) applies to the data made available in this article, unless otherwise stated in a credit line to the data. 
$[14,15]$. Therefore, the eradication of H9N2 LPAIV in poultry becomes more important.

Vaccination is an economic and effective means for preventing and controlling H9N2 LPAIV in poultry. H9N2 LPAIV commercial vaccines consist mainly of the inactivated whole virus, requiring adjuvant for potentiating immunogenicity. Although many adjuvants were evaluated $[16-19,20]$, the current commercial H9N2 LPAIV vaccines cannot provide satisfactory protection against antigenically variant viruses [21, 22]. An ideal adjuvant will not only promote specific immune response, but also improve the type of immune response [23]. However, there were limitations in Th1 or Th2 biased responses generated by commercial H9N2 LPAIV vaccines.

In our previous studies, the total saponin from the stem bark of A. julibrissin and its purified active fraction AJSAF were reported to improve immune responses to ovalbumin, recombinant fowl pox virus vector-based H5 avian influenza vaccine [24], and porcine reproductive and respiratory syndrome virus (PRRSV) vaccine [25] in mice. In this study, AJSAF was evaluated for the adjuvant potentials on immune responses to inactivated H9N2 avian influenza virus vaccine (IH9V) in mice and chicken in comparison with commercially oil-adjuvant.

\section{Results}

Effect on the antigen-specific antibody response in immunized mice

As shown in Fig. 1. AJSAF and Quil A significantly raised serum H9-Ag-specific IgG, IgG1, IgG2a, and
IgG2b antibody titers in IH9V-immunized mice $(P<$ $0.05, P<0.01$, or $P<0.001)$. However, the serum IgG2a and IgG2b antibody titers in the mice immunized with the commercial oil-formulated inactivated H9N2 avian influenza vaccine $(\mathrm{CH} 9 \mathrm{~V})$ were significantly lower than those in the mice immunized with IH9V alone $(P<0.05$ or $P<0.01)$. Meanwhile, the serum H9-Ag-specific IgG, IgG1, IgG2a, and IgG2b antibody titers in the IH9Vimmunized mice were significantly enhanced by AJSAF at 7,10 and 14 days after a single dose of vaccination $(P<0.05, P<0.01$, or $P<0.001$; Fig. 2$)$. In contrast, oil adjuvant only significantly enhanced H9-Ag-specific IgG1 antibody titers at these three time points and IgG antibody titers 10 days after the immunization in the IH9V-immunized mice, respectively. Moreover, H9-Agspecific IgG2a and IgG2b antibody titers in the CH9Vimmunized mice with were significantly lower than those in mice immunized with IH9V alone at 14 days after the immunization.

\section{Effect on $\mathrm{HI}$ and $\mathrm{H}$ 9-Ag-specific $\lg \mathrm{Y}$ antibody levels in immunized chicken}

The chickens were prime- and boost-immunized with IH9V alone or containing AJSAF, or CH9V at 3-week interval. As shown in Fig. 3a, IH9V alone induced lower serum haemagglutination inhibition (HI) antibody titers in chicken after the first immunization. HI antibody titers in chickens immunized with IH9V alone reaches to peak 1 week after a boosting immunization, and after that gradually decreased. AJSAF significantly enhanced

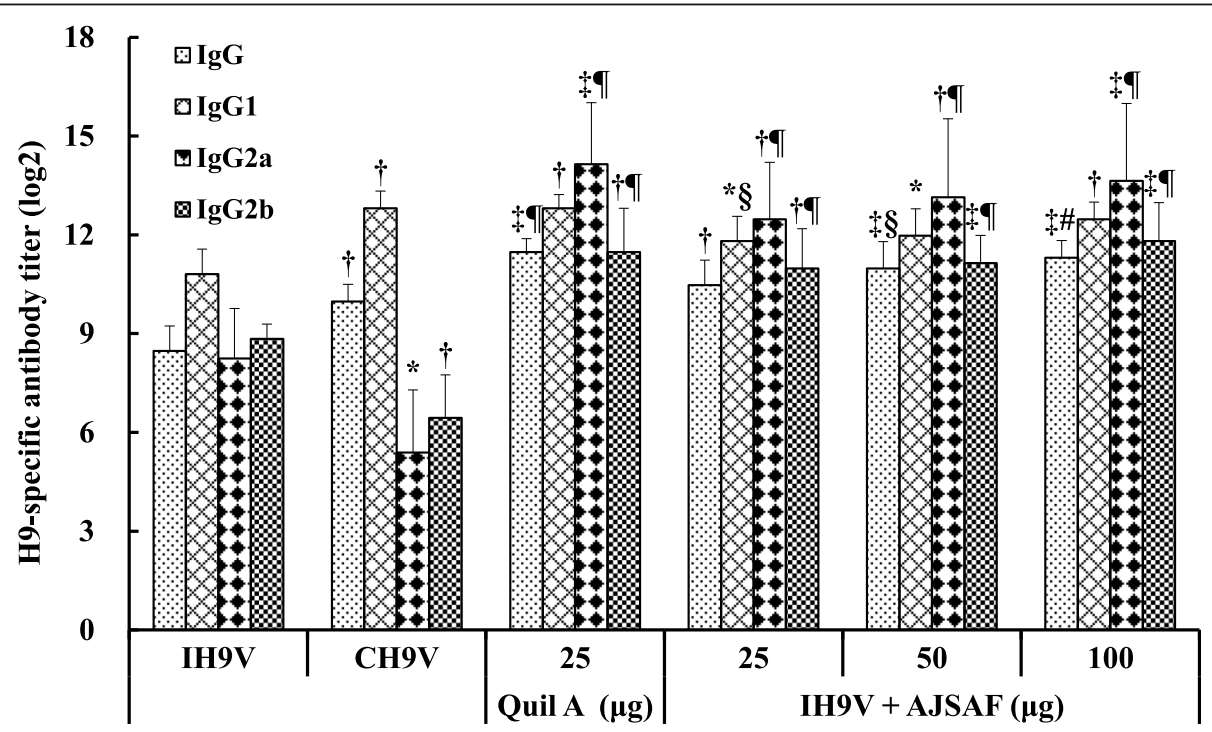

Fig. 1 Effect of AJSAF on H9-Ag-specific lgG and its isotype antibody titers in the immunized mice. Mice were s.c. injected with $0.2 \mathrm{ml}$ of IH9V $\left(10^{7} \mathrm{TCID}_{50} / 0.1 \mathrm{ml}\right)$ alone or containing Quil A or AJSAF, or $0.2 \mathrm{ml}$ of $\mathrm{CH} 9 \mathrm{~V}\left(10^{7} \mathrm{TCID}_{50} / 0.1 \mathrm{ml}\right)$ on days 1 and 15 . Sera were collected 14 days after the boosting immunization, and serum H9-Ag-specific lgG, IgG1, lgG2a, and lgG2b antibody titers were measured by ELISA. The values are presented as means \pm SD $(n=6)$. Significant differences with IHYV alone group were designated as ${ }^{*} P<0.05,{ }^{\dagger} P<0.01$, and ${ }^{\ddagger} p<0.001$; those with CH9V group as ${ }^{\S} P<0.05,{ }^{\#} P<0.01$, and ${ }^{\natural} P<0.001$ 


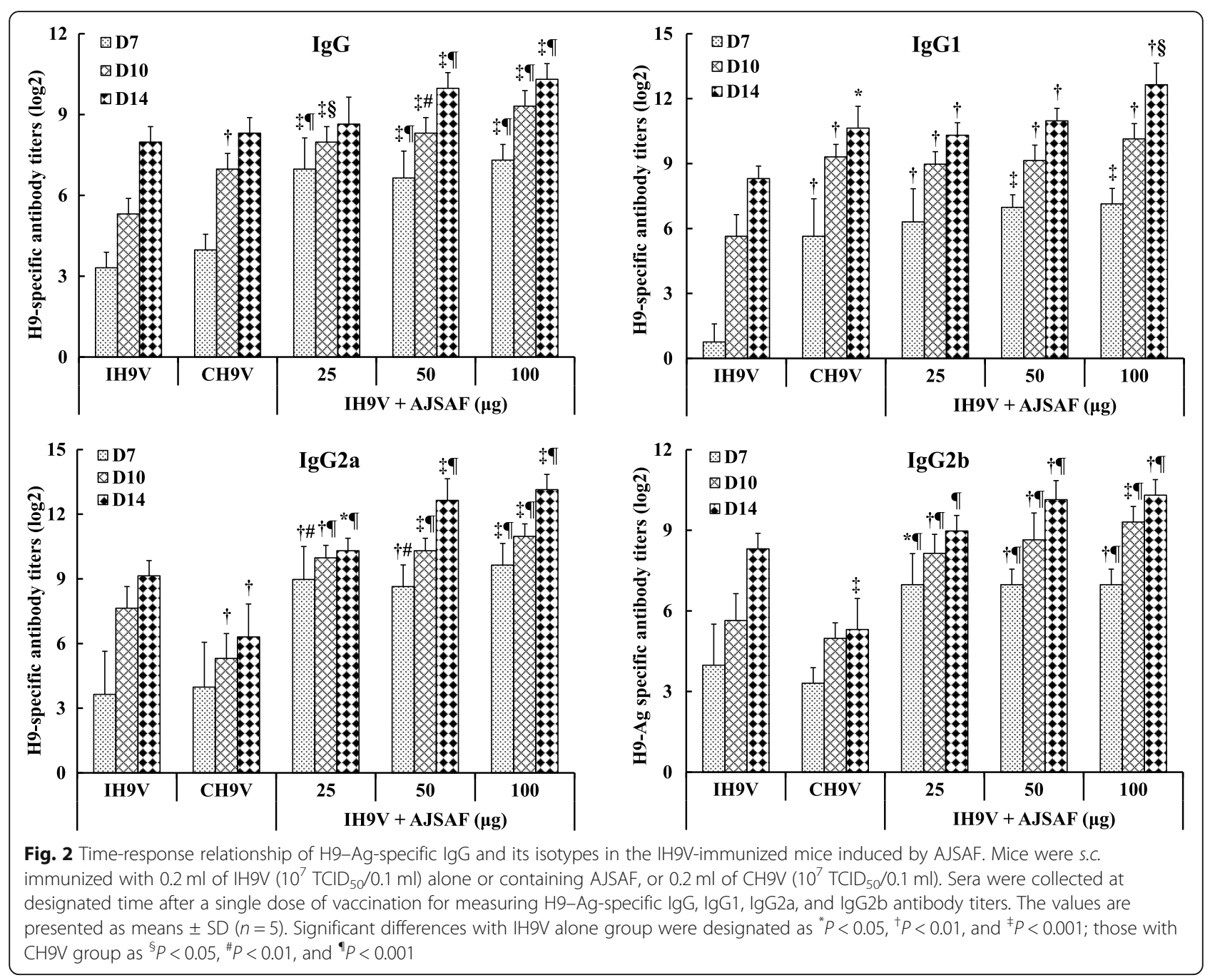

the serum HI antibody titers in IH9V-immunized chickens at all the designated time points. The serum IgY antibody levels in chicken immunized with IH9V/AJSAF and $\mathrm{CH} 9 \mathrm{~V}$ were also significantly higher than those in chicken immunized with IH9V alone at all the designated time points (Fig. 3b).

\section{Effect on splenocyte proliferation in immunized mice}

Splenocyte proliferation was determined using 3-(4,5-dimethylthiazol-2-yl)-2,5-diphenyl- tetrazolium bromide (MTT) method, and the results are shown in Fig. 4. Con A-, LPS-, and H9-Ag-stimulated splenocyte proliferation in the mice immunized with IH9V/AJSAF and IH9V/ Quil A were markedly higher than those in IH9V alone group $(P<0.05, P<0.01$, or $P<0.001)$. There were, however, no significant differences in Con A-, LPS- and H9Ag-stimulated splenocyte proliferation between the IH9V alone and CH9V groups $(P>0.05)$.
Effects on the activity of NK cells in immunized mice As shown in Fig. 5, the immunization with IH9V alone and $\mathrm{CH} 9 \mathrm{~V}$ resulted in the decrease in the killing activity of NK cells in mice $(P<0.05$ or $P<0.01)$. There was no significant difference in NK cell activities was observed between the IH9V alone and $\mathrm{CH} 9 \mathrm{~V}$ groups $(P>0.05)$. However, AJSAF and Quil A significantly promoted the killing activity of NK cells from the splenocytes in the IH9V-immunized mice $(P<0.01$ or $P<0.001)$.

Effect on the secretion of cytokine from the splenocytes in immunized mice

As shown in Fig. 6, AJSAF and Quil A significantly promoted the production of IL-2, IFN- $\gamma$, and IL-10 from Con A- and H9-Ag-stimulated splenocytes of the IH9Vimmunized mice compared with IH9V alone group $(P<$ $0.05, P<0.01$, or $P<0.001)$. There were, however, no significant differences were found in the production of IL2 , IFN- $\gamma$, and IL-10 from Con A- and H9-Ag-stimulated 

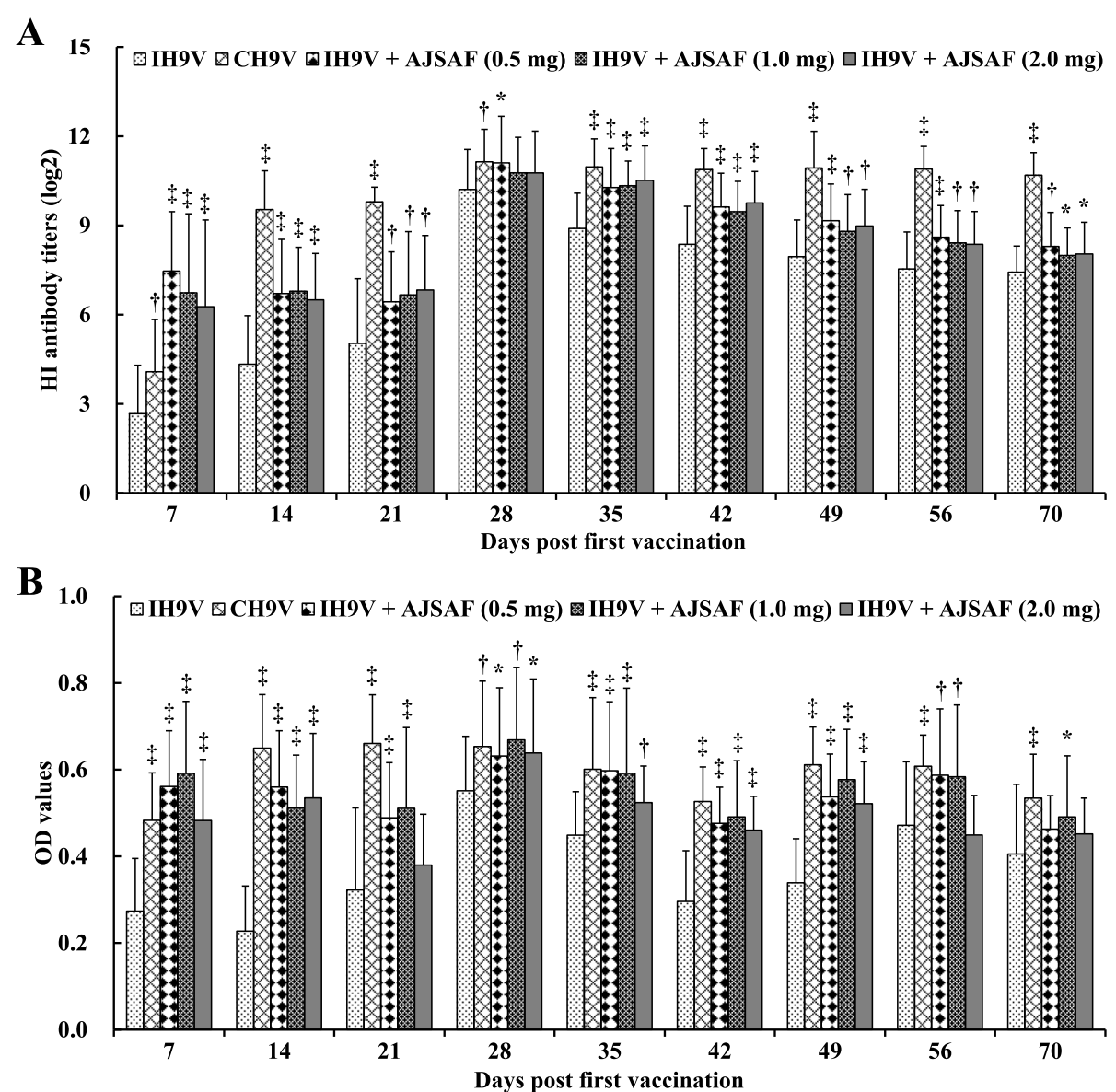

Fig. 3 Effect of AJSAF on haemagglutination inhibition (HI) and H9-Ag-specific IgY antibody levels in the immunized chicken. The chickens were prime- and boost-immunized with $0.4 \mathrm{ml}$ of $\mathrm{IH9V}\left(10^{7} \mathrm{TCID}_{50} / 0.1 \mathrm{ml}\right)$ alone or containing AJSAF, or $0.4 \mathrm{ml}$ of CH9V $\left(10^{7} \mathrm{TCI} \mathrm{D}_{50} / 0.1 \mathrm{ml}\right)$ at 3-week interval. Sera were collected on designated days post-immunization, and the serum HI antibody titers (a) and H9-Ag-specific IgY antibody (b) levels were measured by $\mathrm{HI}$ assay and ELISA, respectively. The values are presented as means $\pm \mathrm{SD}(n=30)$. Significant differences with $I H 9 \mathrm{~V}$ alone group were designated as ${ }^{*} P<0.05,{ }^{\dagger} P<0.01$, and ${ }^{\ddagger} P<0.001$

splenocytes between IH9V alone and CH9V groups $(P>$ $0.05)$. In this experiment, it was also found that the contents of cytokines IL-2, IFN- $\gamma$, and IL-0 in the culture supernatants from $\mathrm{H} 9-\mathrm{Ag}$-stimulated splenocytes in the mice immunized with IH9V alone and CH9V were significantly lower than those in PBS control mice $(P<$ 0.01or $P<0.001$; Fig. 6b).

Effect on the mRNA expression levels of cytokines and transcription factors in splenocytes from immunized mice As shown in Fig. 7, both AJSAF and Quil A significantly up-regulated not only the mRNA expression levels of Th1 (IL-2 and IFN- $\gamma$ ) and Th2 (IL-4 and IL-10) cytokines, but those of Th1 (T-bet and STAT-4) and Th2 (GATA3 and STAT-6) transcription factors in Con Aand $\mathrm{H} 9-\mathrm{Ag}$-stimulated splenocytes from the mice immunized with IH9V $(P<0.05, P<0.01$, or $P<0.001)$. However, the immunization with IH9V alone and CH9V significantly down-regulated the mRNA expression levels of most cytokines and transcription factors in Con A- and H9-Ag-stimulated splenocytes of the mice compared to the PBS control mice $(P<0.05, P<0.01$, or $P<$ $0.001)$.

\section{Discussion}

Vaccination is an important and effective means of controlling H9N2 LPAIV in poultry. However, H9N2 LPAIV underwent significant antigenic drift [26], resulting in that the current commercially available vaccines cannot provide satisfactory protection $[3,22]$. In contrast to $B$ cells that have a subtype- and strains-specific response, the recognition and responses of $\mathrm{T}$ cell to influenza virus do not degrade with antigenic drift. It was reported that $\mathrm{T}$ cell responses were better correlated to influenza vaccine protection than antibody titers in human [27]. An optimal influenza vaccine should be capable of eliciting cell-mediated immunity as well as producing effective antibodies [28]. Consequently, many efforts have been 


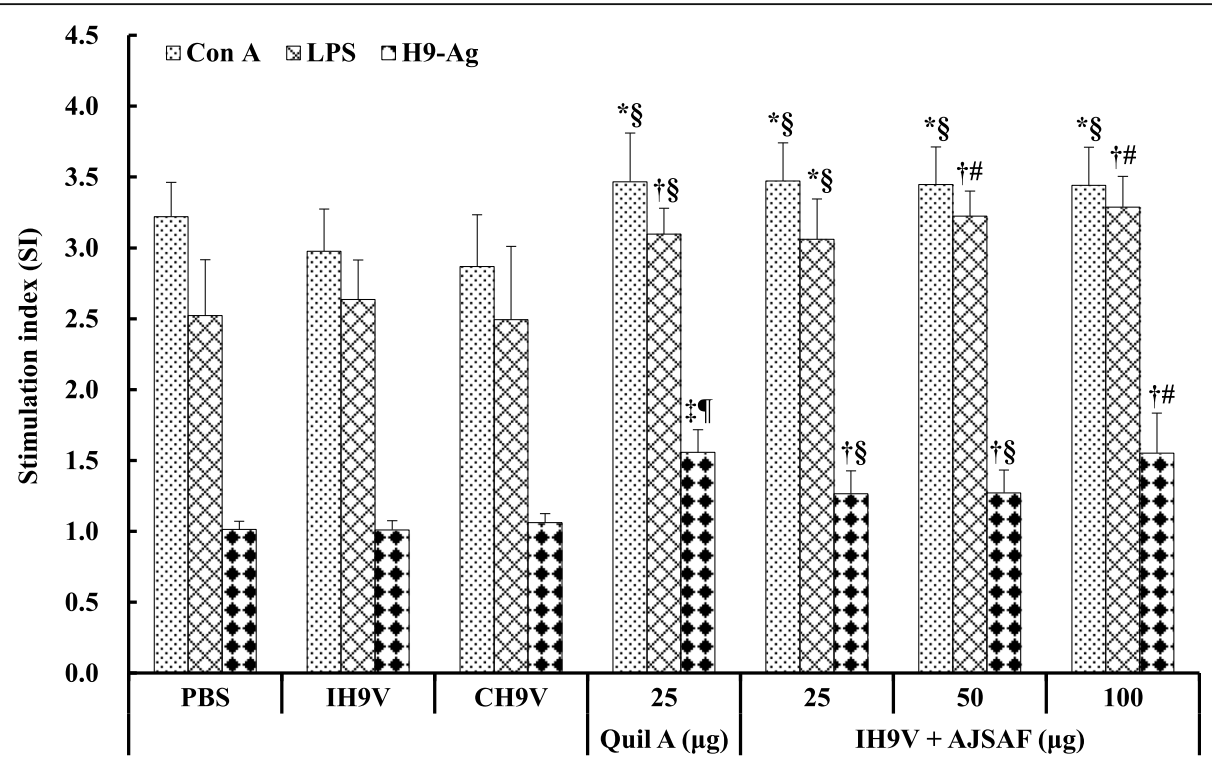

Fig. 4 Effect of AJSAF on Con-, LPS-, and H9-Ag-stimulated splenocyte proliferation in the immunized mice. Splenocyte proliferation was measured by the MTT method and shown as a stimulation index (SI). The values are presented as means \pm SD $(n=6)$. Significant differences with IH9V alone group were designated as ${ }^{*} P<0.05,{ }^{\dagger} P<0.01$, and ${ }^{\ddagger} P<0.001$; those with CH9V group as ${ }^{\S} P<0.05,{ }^{\#} P<0.01$, and ${ }^{\natural} P<0.001$

made to develop novel efficacious adjuvants for inactivated LPAIV vaccine [29-33, 34].

Pedersen et al. [35] reported that the serum virusspecific IgG antibody titers correlated with influenza H5N1 virus neutralization in human. It was also reported that the induction of both IgG1 and IgG2a isotypes was considered to be a better correlate for vaccine efficacy than neutralization in mice [36]. In this study,
AJSAF and Quil A significantly raised serum H9-Agspecific IgG, IgG1, IgG2a, and IgG2b antibody titers in the IH9V-immunized mice (Fig. 1). However, the serum IgG2a and IgG2b antibody titers in the CH9Vimmunized mice were significantly lower than those in the mice immunized with IH9V alone $(P<0.05$ or $P<$ 0.01 ). Meanwhile, the adjuvanticity-time relationship of AJSAF on the humoral immune responses to IH9V in

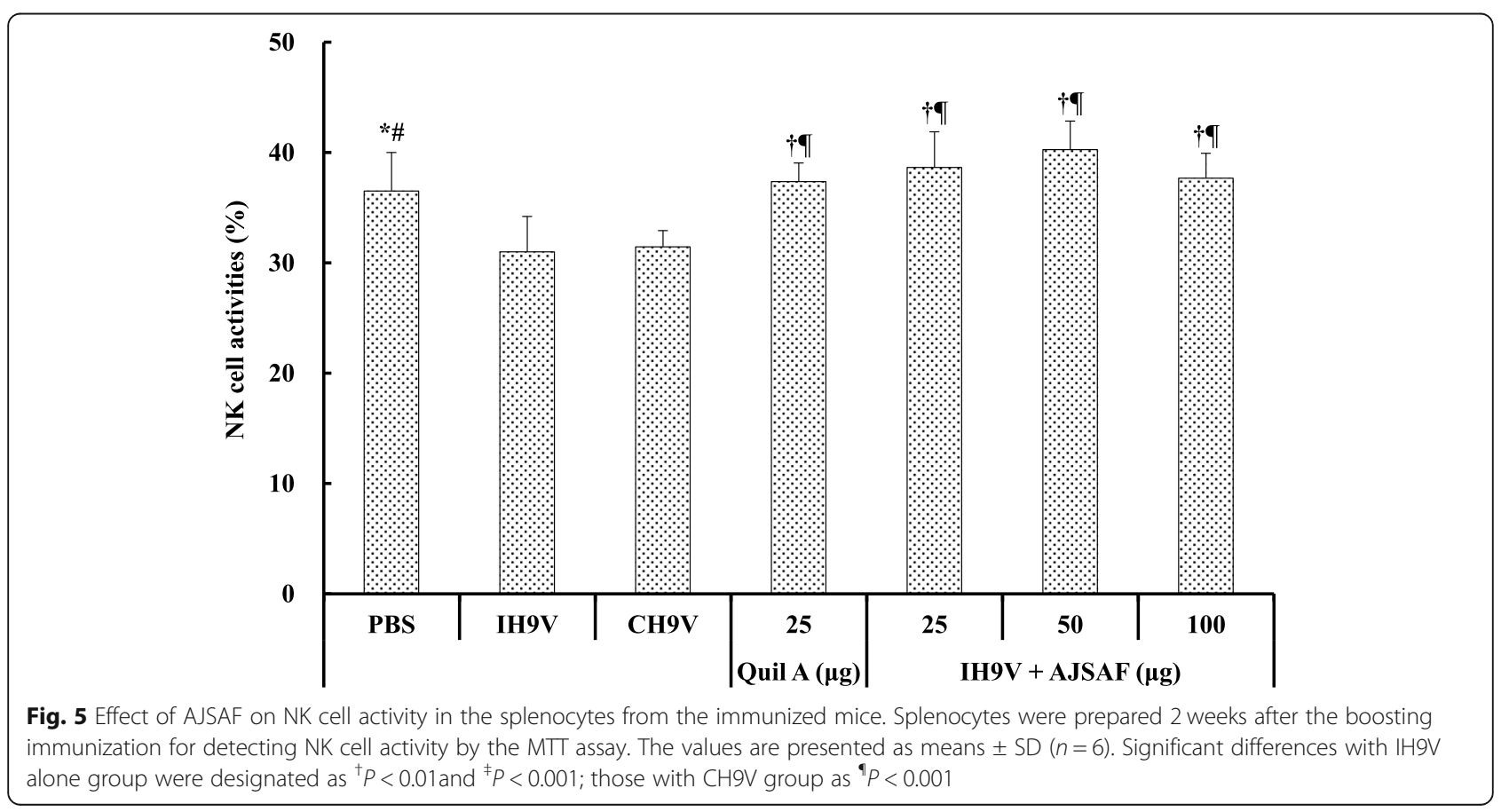



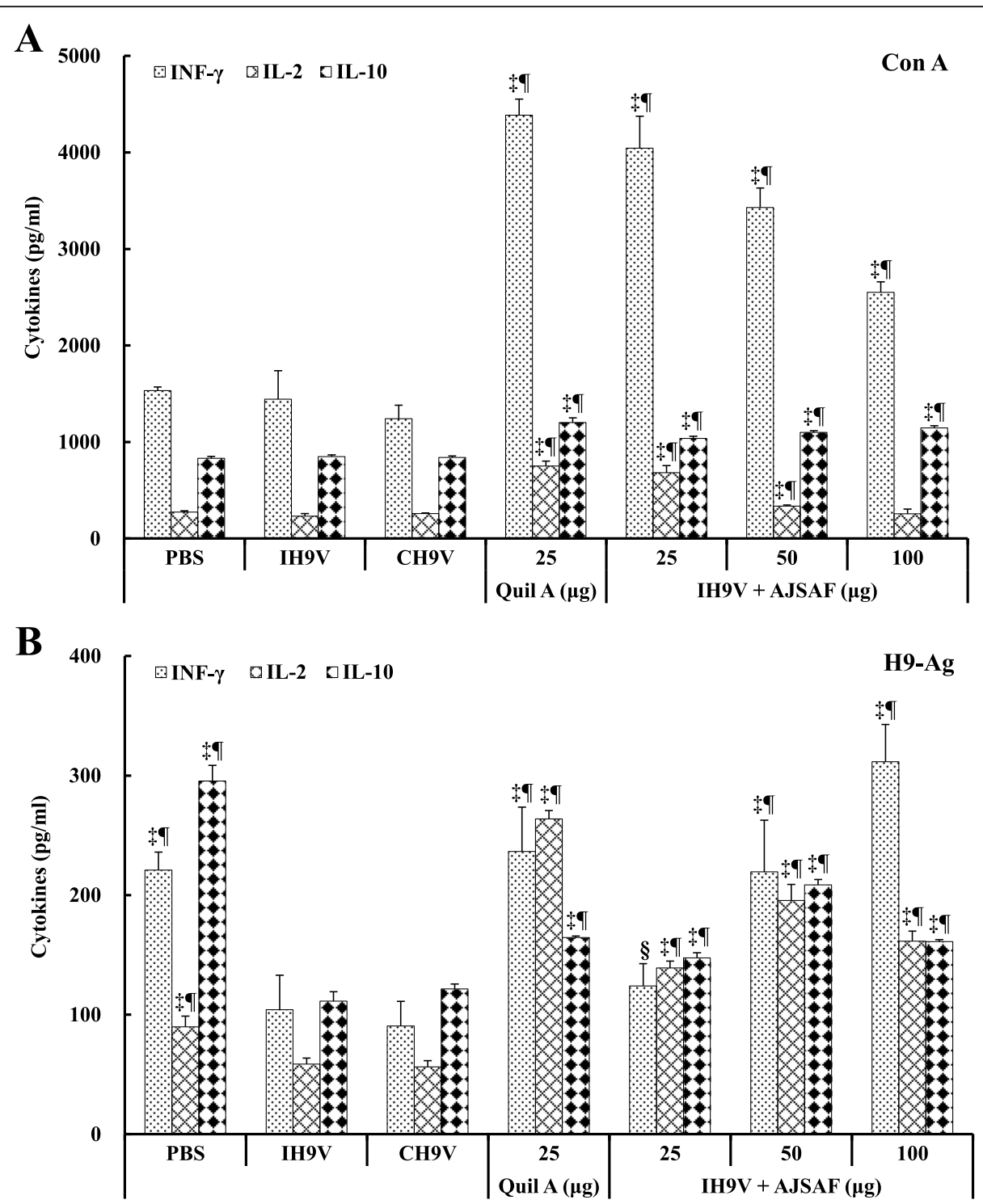

Fig. 6 Effect of AJSAF on cytokine secretion from splenocytes in the immunized mice. Splenocytes were incubated with Con A (48 h) or H9-Ag $(72 \mathrm{~h})$, and the supernatants were collected for detecting IL-2, IFN- $\gamma$, and IL-10 levels using ELISA kits. The values are presented as means \pm SD $(n=6)$. Significant differences with $\mathrm{H} 9 \mathrm{~V}$ alone group were designated as ${ }^{*} P<0.05,{ }^{\dagger} P<0.01$, and ${ }^{\ddagger} P<0.001$; those with $\mathrm{CH} 9 \mathrm{~V}$ group as ${ }^{\#} P<0.01$ and ${ }^{n} P<0.001$

mice was also investigated. The results showed that AJSAF could accelerate the humoral immune responses to IH9V in mice (Fig. 2).

To evaluate the adjuvant effect of AJSAF on immune responses to IH9V and profile the detailed dynamics of the antigen-specific humoral responses, serum $\mathrm{HI}$ and H9-Ag-specific IgY antibody in the immunized chicken were determined. The results showed that AJSAF significantly increased serum both $\mathrm{HI}$ antibody titers and H9Ag-specific IgY levels in IH9V-immunized chickens up to 6 weeks post boosting immunization (Fig. 3). These results suggested that AJSAF could elevate and prolong $\mathrm{HI}$ antibody titers and $\mathrm{H} 9-\mathrm{Ag}$-specific IgY antibody levels in immunized chicken. Interestingly, it was found that AJSAF could produce faster and approximately mean 18- and 7-fold higher antibody response in the chickens than the IH9V alone and CH9V 7 days after the first immunization, respectively. This finding is consistent with the time-course results of H9-Ag-specific IgG and its isotype response to IH9V in mice (Fig. 2), confirming that AJSAF could accelerate the humoral immune responses to IH9V.

The cellular immunity plays an important role in fighting influenza virus infections by limiting virus replication and accelerating clearance of virus-infected cells in mice [37]. The cross-protection responses mediated by 

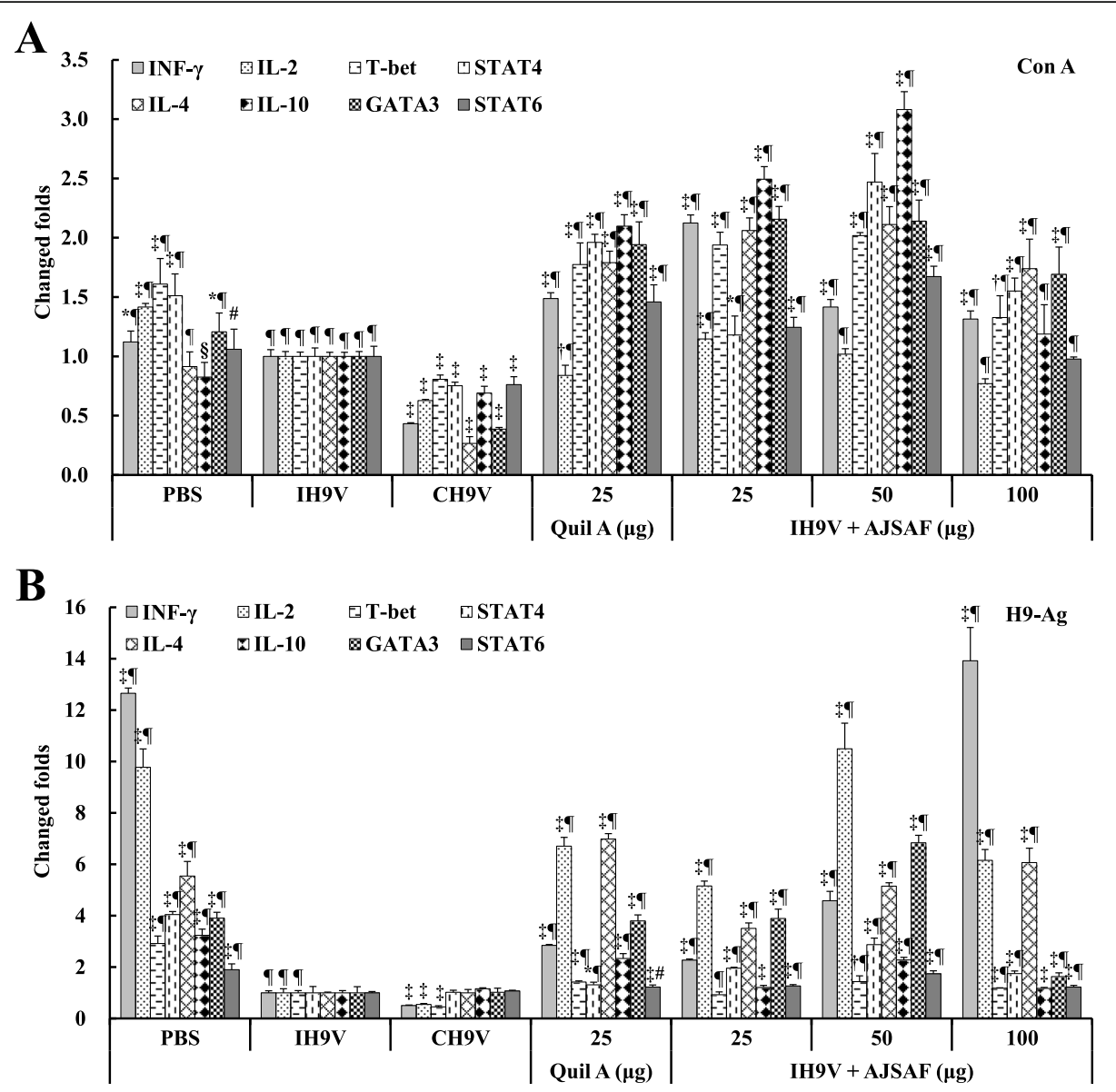

Fig. 7 Effect of AJSAF on mRNA expression of cytokines and transcription factors in Con A (a) - and H9-Ag (b)-stimulated splenocytes from the immunized mice. Splenocytes were incubated with Con A (for $12 \mathrm{~h}$ ) or H9-Ag (for $16 \mathrm{~h}$ ), and the mRNA expression levels of cytokines and transcription factors were measured using RT-qPCR. The values are presented as means \pm SD $(n=6)$. Significant differences with IH9V alone group were designated as ${ }^{*} P<0.05,{ }^{\dagger} P<0.01$, and ${ }^{\ddagger} P<0.001$; those with CH9V group as ${ }^{\S} P<0.05,{ }^{\#} P<0.01$, and ${ }^{\circledR} P<0.001$

influenza virus specific $\mathrm{T}$ cells directed not only towards conserved proteins such as nucleoprotein, but also to conserved sequences in hemagglutinin in mice [38]. To clarify the capacity of AJSAF to elicit effective T- and Blymphocyte immunity, the Con A-, LPS-, and H9-Agstimulated splenocyte proliferation in the immunized mice was detected. The proliferation assay showed that AJSAF significantly promoted Con A-, LPS-, and H9Ag-stimulated splenocyte proliferation in the IH9Vimmunized mice. AJSAF was more effective than oil adjuvant in inducing strong activation potential of $\mathrm{T}$ and $\mathrm{B}$ cells, and could induce the humoral immunity and cellmediated immune response to IH9V in mice (Fig. 4). In this investigation, the addition of oil-adjuvant to IH9V did also not result in increase in the killing activity of NK cells in the immunized mice. In contrast, AJSAF significantly promoted the NK cell activity in IH9Vimmunized mice (Fig. 5), suggesting that the usage of AJSAF in IH9V could help to improve cytolytic activities against H9N2 LPAIV. These results suggested that
AJSAF could elicit the cellular immune responses to IH9V in mice.

In order to clearly investigate that Th cell-derived cytokine profiles in IH9V-immunized mice, the contents of Th1 (IL-2 and IFN- $\gamma$ ) and Th2 (IL-10) cytokines in the culture supernatant of Con A- and H9-Ag-stimulated splenocytes were detected using ELISA kits. AJSAF significantly induced the production of IFN- $\gamma$, IL-2, and IL-10 from splenocytes in IH9V-immunized mice responding to Con $\mathrm{A}$ and $\mathrm{H} 9-\mathrm{Ag}$ (Fig. 6), suggesting that AJSAF could improve cell-mediated immunity and trigger dual Th1 and Th2 responses to IH9V.

To further elucidate the mechanism responsible for the efficacy of AJSAF on the Th1 and Th2 responses, the mRNA expression levels of cytokines and transcription factors in Con A- and H9-Ag-stimulated splenocytes from immunized mice were measured using RTqPCR. AJSAF up-regulated the mRNA expression levels of not only Th2 cytokines (IL-4 and IL-10) and transcription factors (GATA3 and STAT-6), but also Th1 
cytokines (IFN- $\gamma$ and IL-2) and transcription factors (Tbet and STAT-4) (Fig. 7). The high mRNA expression of Th1 cytokines and transcription factors in splenocytes was consistent with the high IgG2a and IgG2b titers, while the high mRNA expression of Th2 cytokines and transcription factors was consistent with the high levels of IgG1 antibodies in mice immunized with IH9V/ AJSAF [39]. Together, these results further confirmed that AJSAF improved the quality of the immune responses and elicited both Th1 and Th2 immune response to IH9V.

In addition, our experiment results also demonstrated that the immunization with $\mathrm{IH} 9 \mathrm{~V}$ and $\mathrm{CH} 9 \mathrm{~V}$, especially the latter, impaired the cell-mediated immunity in mice, highlighting the crucial role of the adjuvant with enhanced cell-mediated immunity in effective vaccines against H9N2 LPAIV.

\section{Conclusions}

In summary, this investigation demonstrated that AJSAF had immunological adjuvant activity on specific cellular and humoral immune responses and triggered both Th1 and Th2 responses to IH9V in mice. Most importantly, AJSAF could produce faster and higher HI antibody and virus-specific IgY response in chicken as well as antigenspecific antibody titers in mice. Hence, AJSAF may be an efficient adjuvant candidate for IH9V. This study also suggested that AJSAF-primed and oil-boosted regimen might produce encouraging results associated with quick, persistent and improved immune responses to inactivated H9N2 avian influenza vaccine, and be an economical and effective strategy for H9N2 LPAI prevention in poultry. This strategy and the clinical protective efficacy of AJSAF combined with IH9V on H9N2 LPAI needs to be further evaluated by the challenge test in chickens.

\section{Methods \\ Materials}

Concanavalin A (Con A), lipopolysaccharide (LPS), rabbit anti-mouse IgG peroxidase conjugate, RPMI medium, and 3-(4,5-dimethylthiazol-2-yl)-2,5-diphenyltetrazolium bromide (MTT) were purchased from Sigma Co., St. Louis, MO, USA; fetal calf serum was from Hyclone, Utah, USA; goat anti-mouse IgG1, IgG2a, and IgG2b peroxidase-conjugates were from Southern Biotech. Assoc., Birmingham, AL, USA; rabbit anti-chicken IgY horseradish peroxidase conjugate was from Promega Corporation, Madison, WI, USA; mouse cytokine detecting ELISA kits were from Wuhan Boster Bio-Tech. Co. Ltd., China; Trizol was from Invitrogen, Carlsbad, CA, USA; FastStart universal SYBR Green Master (ROX) was from Roche Diagnostics, Indianapolis, IN, USA. Quil A was gifted by Brenntag Nordic A/S, Hellerup, Denmark.

\section{Vaccines and viruses}

The formaldehyde-inactivated H9N2 avian influenza virus (A/Chicken/Shanghai/1/98 [AIV H9N2 subtype, F Strain]) (IH9V) and its commercially oil-formulated vaccine (CH9V) were provided with Zhejiang CEVA EBVAC Biotech Co., Ltd., Hangzhou, China. IH9V and CH9V belong to the same lot (14008P) and both contain $10^{7} 50 \%$ tissue culture infective doses $\left(\mathrm{TCID}_{50}\right) / 0.1 \mathrm{ml}$. H9 subtype avian influenza virus antigen $(\mathrm{H} 9-\mathrm{Ag})$, positive and negative serum were purchased from Beijing Kangnongxinmu Technology Development Center, Beijing, China.

\section{Preparation and characterization of AJSAF}

The purified fraction of Albizia julibrissin saponins (AJSAF) was prepared and characterized as previously described [25]. A total of 29 saponins including 10 new compounds and 5 first found saponins from A. julibrissin were identified and characterized in AJASF by highperformance liquid chromatography coupled with quadrupole time-of-flight mass spectrometry based on accurate mass database [40].

\section{Experimental animals and immunization}

Female ICR mice aged 5-6 weeks were purchased from Shanghai Experimental Animal Center of Chinese Academy of Sciences, Shanghai, China (certificate no. SCXK 2007-0005). SPF white Leghorn chickens were provided by Hangzhou Laying Hen Farm, Zhejiang, China. Animals were acclimatized for 1 week prior to use. Rodent laboratory chow and tap water were provided ad libitum and maintained under controlled conditions with a temperature of $24 \pm 1{ }^{\circ} \mathrm{C}$, humidity of $50 \pm 10 \%$, and a 12/12-h light/dark cycle.

In the experiment to evaluate the adjuvant effects of AJSAF on IH9V, mice were divided into seven groups, with six mice per group. Mice were subcutaneously (s.c.) injected with $0.2 \mathrm{ml}$ of IH9V $\left(10^{7} \mathrm{TCID}_{50} / 0.1 \mathrm{ml}\right)$ alone or containing Quil A $(10 \mu \mathrm{g})$, or $\operatorname{AJSAF}(25,50$, or $100 \mu \mathrm{g}$ ) on day 1 . A boosting injection was given 14 days later. Animals injected with $0.2 \mathrm{ml}$ of $\mathrm{PBS}$ and $\mathrm{CH} 9 \mathrm{~V}$ $\left(10^{7} \mathrm{TCID}_{50} / 0.1 \mathrm{ml}\right)$ were included as a negative and positive control, respectively. Sera and splenocytes were collected Two weeks after the boosting immunization.

In adjuvanticity-time analysis experiment, mice were divided into six groups of fifteen mice each. Mice were s.c. immunized with $0.2 \mathrm{ml}$ of IH9V $\left(10^{7} \mathrm{TCID}_{50} / 0.1 \mathrm{ml}\right)$ alone or containing $\operatorname{AJSAF}(25,50$, or $100 \mu \mathrm{g})$, or $0.2 \mathrm{ml}$ of $\mathrm{CH} 9 \mathrm{~V}\left(10^{7} \mathrm{TCID}_{50} / 0.1 \mathrm{ml}\right)$ on day 1 . Saline-treated mice were included as controls. Five mice per group were randomly sacrificed at 7,10 , and 14 days after the immunization, and sera were collected for measurement of H9-Ag-specific antibody titers. All the animals were euthanized in a chamber with carbon dioxide. Blood was drawn from the eyes and the serum was prepared by 
centrifuging at $3500 \mathrm{rpm}$ for $10 \mathrm{~min}$ at $4{ }^{\circ} \mathrm{C}$. The mice were then sacrificed via cervical dislocation, and the spleens were collected.

35-day-old SPF white Leghorn chickens were divided into five groups of 30 chickens each, and intramuscularly (i.m.) immunized with $0.4 \mathrm{ml}$ of IH9V $\left(10^{7} \mathrm{TCID}_{50} / 0.1\right.$ $\mathrm{ml}$ ) alone or containing $\operatorname{AJSAF}(0.5,1.0$, or $2.0 \mathrm{mg}$ ), or $0.4 \mathrm{ml}$ of $\mathrm{CH} 9 \mathrm{~V}\left(10^{7} \mathrm{TCID}_{50} / 0.1 \mathrm{ml}\right)$ on day 1 . A boosting injection was given 3 weeks later. Sera were collected at 1- or 2-week intervals for measurement of antibody. Finally, all chickens were euthanized by intravenous injection with pentobarbital sodium at the dose $40 \mathrm{mg} / \mathrm{kg}$ followed by cervical dislocation.

\section{Measurement of serum H9-Ag-specific antibody}

Serum H9-Ag-specific IgG antibody and its isotypes in mice and IgY antibody in chicken were detected by an indirect ELISA as previously described [41]. The optical density was measured at $492 \mathrm{~nm}$ using a BIO-RAD 680 ELISA reader. The mean OD value of the sample was subtracted from that of the control. Where sets of serum samples have been subjected to within and between group comparisons, ELISA assays were performed on the same day for all of the samples.

\section{Haemagglutination inhibition (HI) assay}

The serum inactivated at $56^{\circ} \mathrm{C}$ for $30 \mathrm{~min}$ was two-fold serially diluted with PBS. The diluted serum was added to 96-well V-bottom plates, and then incubated with an equal volume of $\mathrm{H} 9-\mathrm{Ag}$ (4 hemagglutinating units (HAU)) for $30 \mathrm{~min}$ at room temperature. An equal volume of $1 \%$ chicken red blood cells were added, and the plates were incubated for further $30 \mathrm{~min}$. The positive and negative sera were included as controls. The $\mathrm{HI}$ titers were represented as the $\log 2$ of the reciprocal of the highest serum dilution leading to complete HI [17].

\section{Splenocyte proliferation assay}

Splenocytes $\left(5 \times 10^{6}\right.$ cells $\left./ \mathrm{ml}\right)$ were incubated with Con A $(5 \mu \mathrm{g} / \mathrm{ml})$, LPS $(10 \mu \mathrm{g} / \mathrm{ml}), \mathrm{H} 9-\mathrm{Ag}(0.125 \mathrm{HAU} / \mathrm{ml})$, or medium in 96-well culture plate at $37{ }^{\circ} \mathrm{C}$ and $5 \% \mathrm{CO}_{2}$. After $44 \mathrm{~h}$ (Con A and LPS) or $68 \mathrm{~h}$ (H9-Ag), splenocyte proliferation was detected using MTT assay as previously described [40], and shown as the stimulation index (SI).

\section{Assay of NK cell activity}

The activity of NK cells in splenocytes was measured by MTT assay using human leukemia K562 cell lines as target cells as previously described [42]. Three kinds of control measurements were performed: target cells control, blank control and effector cells control. NK cell activity was calculated as following equation: NK activity $(\%)=\left(\mathrm{OD}_{\mathrm{T}}-\left(\mathrm{OD}_{\mathrm{S}}-\mathrm{OD}_{\mathrm{E}}\right)\right) / \mathrm{OD}_{\mathrm{T}} \times 100$, where $\mathrm{OD}_{\mathrm{T}}$, absorbance of target cells control, $\mathrm{OD}_{\mathrm{S}}$, absorbance of test samples and $\mathrm{OD}_{\mathrm{E}}$, absorbance of effector cells control.

\section{Cytokine measurements}

Splenocytes $\left(5 \times 10^{6}\right.$ cells/well $)$ were incubated with Con A $(5 \mu \mathrm{g} / \mathrm{ml})$ and $\mathrm{H} 9-\mathrm{Ag}(0.125 \mathrm{HAU} / \mathrm{ml})$ in 24-well culture plates at $37^{\circ} \mathrm{C}$ in $5 \% \mathrm{CO}_{2}$ for 48 and $72 \mathrm{~h}$, respectively. The supernatants were collected for detecting contents of cytokines (IL-2, IL-10, and IFN- $\gamma$ ) using ELISA kits [43].

\section{Real-time quantitative PCR (RT-qPCR)}

Splenocytes were incubated with Con A $(2.5 \mu \mathrm{g} / \mathrm{ml})$ and $\mathrm{H} 9-\mathrm{Ag}(0.125 \mathrm{HAU} / \mathrm{ml})$ in 24-well culture plates for 12 and $16 \mathrm{~h}$ at $37^{\circ} \mathrm{C}$ in $5 \% \mathrm{CO}_{2}$, respectively. The cells were harvested and subjected to Trizol reagent to isolate total RNA. The reverse transcription was conducted as previously described [44]. The qPCR was performed on an ABI PRISM ${ }^{\bullet} 7300$ PCR System using FastStart Universal SYBR Green Master. The sequences of primers for qPCR were listed in Table S1. The qPCR cycling was performed as follows: one cycle at $95^{\circ} \mathrm{C}$ for $10 \mathrm{~min}$, followed by 40 cycles of denaturation at $95^{\circ} \mathrm{C}$ for $15 \mathrm{~s}$, and then annealing at $60^{\circ} \mathrm{C}$ for $1 \mathrm{~min}$. The mRNA expression levels of the tested genes relative to GAPDH were determined using the $2^{-\Delta \Delta \mathrm{Ct}}$ method and as fold induction.

\section{Statistical analysis}

Data were expressed as mean \pm SD and the statistical significance of difference was analyzed with ANOVA and a Tukey post-hoc test. $P$-value less than 0.05 was considered to be statistically significant.

\section{Supplementary Information}

The online version contains supplementary material available at https://doi. org/10.1186/s12917-020-02648-1.

Additional file 1: Table S1. Primer used for RT-qPCR.

\section{Abbreviations}

AJSAF: Purified active saponin fraction from the dry stem bark of Albizzia julibrissin; CH9V: Commercial oil-formulated H9N2 avian influenza vaccine; Con A: Concanavalin A; ELISA: Enzyme-linked immunosorbent assay; H9Ag: H9 subtype avian influenza viruses antigen; HAU: Hemagglutinating unit; $\mathrm{HI}$ : Haemagglutination inhibition; IH9V: Inactivated H9N2 avian influenza virus vaccine; LPAIV: Low pathogenic avian influenza virus; LPS: lipopolysaccharide; MTT: 3-(4,5-dimethylthiazol-2-yl)-2,5-diphenyl-tetrazolium bromide; NK cell: Natural killer cell; RT-qPCR: real-time quantitative polymerase chain reaction; Quil A: Total saponin from Quillaja saponaria Molina; $\mathrm{TCID}_{50}$ : 50\% tissue culture infective doses

\section{Acknowledgments}

We thank Shixin Hua from Hangzhou Laying hen Farm (Zhejiang, China) for his help with the chicken experiment. We also sincerely appreciate other colleagues in our laboratory for their help and effort in this study. 


\section{Authors' contributions}

LYF, BNZ, MHS and HXS conducted all experiments, collected and analyzed the data. HXS designed the experiments and wrote the manuscript. All authors read and approved the final manuscript.

\section{Funding}

This work was supported by the National Key R\&D Program of China (No. 2017YFD0501500), the National Natural Science Foundation of China (Nos. 31472229 and 31772783), the Zhejiang Provincial Natural Science Foundation of China (No. LZ13C180001), the 948 Project of Ministry of Agriculture (No. 2013-S17), and a project funded by the Dabeinong Funds for Discipline Development and Talent Training in Zhejiang University.

\section{Availability of data and materials}

The data analyzed during the current study are are included in this published article.

\section{Ethics approval and consent to participate}

All the procedures were in strict accordance with the China legislation on the use and care of laboratory animals and with the guidelines established by Institute for Experimental Animals of Zhejiang University. The experimental animal facility and procedures were approved by the Institutional Animal Care and Use Committee of Zhejiang University.

\section{Consent for publication}

Not applicable.

\section{Competing interests}

The authors declare that they have no competing interests.

\section{Received: 8 February 2020 Accepted: 28 October 2020}

Published online: 07 November 2020

\section{References}

1. Lee DH, Fusaro A, Song CS, Suarez DL, Swayne DE. Poultry vaccination directed evolution of H9N2 low pathogenicity avian influenza viruses in Korea. Virology. 2016:488:225-31.

2. Lau EH, Zhang SQ, Leung C, Cowling BJ, Wu JT, Peiris M. Identifying key transmission route of avian influenza A (H9N2) in live poultry markets. Online J Public Health Inform. 2017;9:e106.

3. Zhao YF, Diao FF, Yu JY, Zhang FX, Jiang CQ, Wang JL, Guo SY, Cui K, Liu CY, Wei XH, Jiang SJ, Xie ZJ. Intraspecies and interspecies transmission of mink H9N2 influenza virus. Sci Rep. 2017;7:7429.

4. Jaleel S, Younus M, Idrees A. Arshad M, khan AU, Ehtisham-ul-Haque S, Zaheer MI, Tanweer M, Towakal F, Munibullah, Tipu MY, Sohail ML, Umar S. pathological alterations in respiratory system during co-infection with low pathogenic avian influenza virus (H9N2) and Escherichia coli in broiler chickens. J Vet Res. 2017;61:253-8.

5. Arafat N, Eladl AH, Marghani BH, Saif MA, El-Shafei RA. Enhanced infection of avian influenza virus H9N2 with infectious laryngeotracheitis vaccination in chickens. Vet Microbiol. 2018;219:8-16.

6. Eladl AH, Alzayat AA, Ali HS, Fahmy HA, Ellakany HF. Comparative molecular characterization, pathogenicity and seroprevalence of avian influenza virus H9N2 in commercial and backyard poultry flocks. Comp Immunol Microbiol Infect Dis. 2019;64:81-9.

7. Matrosovich MN, Krauss S, Webster RG. H9N2 influenza A viruses from poultry in Asia have human virus-like receptor specificity. Virology. 2001;281: 156-62.

8. Lin YP, Shaw M, Gregory V, Cameron K, Lim W, Klimov A, Subbarao K, Guan Y, Krauss S, Shortridge K, Webster R, Cox N, Hay A. Avian-to-human transmission of H9N2 subtype influenza A viruses: relationship between H9N2 and H5N1 human isolates. Proc Natl Acad Sci U S A. 2000;97:9654-8.

9. Butt KM, Smith GJ, Chen H, Zhang LJ, Leung YH, Xu KM, Lim W, Webster RG, Yuen KY, Peiris JS, Guan Y. Human infection with an avian H9N2 influenza A virus in Hong Kong in 2003. J Clin Microbiol. 2005;43:5760-7.

10. Kim SH. Challenge for one health: co-circulation of zoonotic H5N1 and H9N2 avian influenza viruses in Egypt. Viruses. 2018;10:121.

11. Gao R, Cao B, Hu Y, Feng Z, Wang D, Hu W, Chen J, Jie Z, Qiu H, Xu K, Xu X, Lu H, Zhu W, Gao Z, Xiang N, Shen Y, He Z, Gu Y, Zhang Z, Yang Y, Zhao X, Zhou L, Li X, Zou S, Zhang Y, Li X, Yang L, Guo J, Dong J, Li Q, Dong L, Zhu Y, Bai T, Wang S, Hao P, Yang W, Zhang Y, Han J, Yu H, Li D, Gao
GF, Wu G, Wang Y, Yuan Z, Shu Y. Human infection with a novel avianorigin influenza A (H7N9) virus. N Engl J Med. 2013;368:1888-97.

12. Liu D, Shi W, Shi Y, Wang D, Xiao H, Li W, Bi Y, Wu Y, Li X, Yan J, Liu W, Zhao G, Yang W, Wang Y, Ma J, Shu Y, Lei F, Gao GF. Origin and diversity of novel avian influenza A H7N9 viruses causing human infection: phylogenetic, structural, and coalescent analyses. Lancet. 2013;381:1926-32.

13. Sun YP, Liu JH. H9N2 influenza virus in China: a cause of concern. Protein Cell. 2015;6:18-25.

14. Luo CR, Zhao XN, Ning DM, Li D, Xu W. Discovery and response of the first case of human infection with avian influenza A (H9N2) virus in Yunnan Province, China. Chin J Zoonoses. 2017;33:241-4.

15. Huang YG, Jing ZC, Tong JW, Yu SS, Li GQ. 1 case of human infection with the investigation of H9N2 avian influenza disposal report in Mengzi city of Yunnan in 2016. J Med Pest Control. 2017;33:1085-7.

16. Kilany WH, Bazid AH, Ali A, El-Deeb AH, El-Abideen MA, Sayed ME, El-Kady MF. Comparative effectiveness of two oil adjuvant-inactivated avian influenza H9N2 vaccines. Avian Dis. 2016; 60 Suppl 1:226-31.

17. Shin JH, Mo JS, Kim JN, Mo I, Ha BD. Assessment of the safety and efficacy of low pathogenic avian influenza (H9N2) virus in inactivated oil emulsion vaccine in laying hens. J Vet Sci. 2016;17:27-34.

18. Ali ZM, Hassan MAEM, Hussein HA, Ahmed BM, El Sanousi AAE. Protective efficacy of combined trivalent inactivated ISA 71 oil adjuvant vaccine against avian influenza virus subtypes ( $\mathrm{H} 9 \mathrm{~N} 2$ and $\mathrm{H} 5 \mathrm{~N} 1)$ and Newcastle disease virus. Vet World. 2017;10:1212-20.

19. Lone NA, Spackman E, Kapczynski D. Immunologic evaluation of 10 different adjuvants for use in vaccines for chickens against highly pathogenic avian influenza virus. Vaccine. 2017;35:3401-8.

20. Riaz A, Shah MA, Hasan MU. Yameen M, Chaudhry M, Malik A, Zafar MA, Rehman SU, Gawri I. Comparative efficacy of different adjuvant containing inactivated vaccines against low-pathogenicity avian influenza H9N2 virus. Adv Life Sci. 2017:4:66-71.

21. Zhang AG, Lai HZ, Xu JH, Huang WK, Liu YF, Zhao DW, Chen RA. Evaluation of the protective efficacy of Poly l:C as an adjuvant for H9N2 subtype Avian influenza inactivated vaccine and its mechanism of action in ducks. PLoS One. 2017;12:e0170681.

22. Zhao J, Yang HM, Xu HJ, Ma ZB, Zhang GZ. Efficacy of an inactivated bivalent vaccine against the prevalent strains of Newcastle disease and H9N2 avian influenza. Virol J. 2017:14:56.

23. Bonam SR, Partidos CD, Skm H, Muller S. An overview of novel adjuvants designed for improving vaccine efficacy. Trends Pharmacol Sci. 2017;38:77193.

24. Sun HX, He SW, Shi MH. Adjuvant-active fraction from Albizzia julibrissin saponins improves immune responses by inducing cytokine and chemokine at the site of injection. Int Immunopharmacol. 2014;22:346-55.

25. Zhu BN, He TY, Gao XY, Shi MH, Sun HX. Evaluation and characteristics of immunological adjuvant activity of purified fraction of Albizia julibrissin saponins. Immunol Invest. 2019;48:283-302.

26. Sun YP, Pu J, Jiang ZL, Guan T, Xia YJ, Xu Q, Liu LQ, Ma B, Tian FL, Brown EG, Liu JH. Genotypic evolution and antigenic drift of H9N2 influenza viruses in China from 1994 to 2008. Vet Microbiol. 2010;146:215-25.

27. McElhaney JE, Xie D, Hager WD, Barry MB, Wang Y, Kleppinger A, Ewen C, Kane KP, Bleackley RC. T cell responses are better correlates of vaccine protection in the elderly. J Immunol. 2006;176:6333-9.

28. Wack A, Baudner BC, Hilbert AK, Manini I, Nuti S, Tavarini S. Combination adjuvants for the induction of potent, long-lasting antibody and T-cell responses to influenza vaccine in mice. Vaccine. 2008;26:552-61.

29. Lee DH, Kwon JS, Lee HJ, Lee YN, Hur W, Hong YH, Lee JB, Park SY, Choi IS, Song CS. Inactivated H9N2 avian influenza virus vaccine with gel-primed and mineral oil-boosted regimen could produce improved immune response in broiler breeders. Poultry Sci. 2011;90:1020-2.

30. Li DY, Xue MY, Wang C, Wang JB, Chen PY. Bursopentine as a novel immunoadjuvant enhances both humoral and cell-mediated immune responses to inactivated H9N2 avian influenza virus in chickens. Clin Vaccine Immunol. 2011;18:1497-502.

31. Singh SM, Alkie TN, Hodgins DC, Nagy É, Shojadoost B, Sharif S. Systemic immune responses to an inactivated, whole H9N2 avian influenza virus vaccine using class B CpG oligonucleotides in chickens. Vaccine. 2015;33: 3947-52.

32. Awadin WF, Eladl AH, El-Shafei RA, El-Adl MA, Ali HS. Immunological and pathological effects of vitamin E with Fetomune Plus ${ }^{\oplus}$ on chickens 
experimentally infected with avian influenza virus H9N2. Vet Microbiol. 2019; 231:24-32.

33. Eladl AH, Arafat N, El-Shafei RA, Farag VM, Saleh RM, Awadin WF. Comparative immune response and pathogenicity of the H9N2 avian influenza virus after administration of Immulant ${ }^{\oplus}$, based on Echinacea and Nigella sativa, in stressed chickens. Comp Immunol Microbiol Infect Dis. 2019;65:165-175

34. Eladl AH, Mosad SM, El-Shafei RA, Saleh RM, Ali HS, Badawy BM, Elshal MF. Immunostimulant effect of a mixed herbal extract on infectious bursal disease virus (IBDV) vaccinated chickens in the context of a co-infection model of avian influenza virus H9N2 and IBDV. Comp Immunol Microbiol Infect Dis, 2020;72:101505.

35. Pedersen GK, Höschler K, Solbak SM, Bredholt G, Pathirana RD, Afsar A, Breakwell L, Nøstbakken JK, Raae AJ, Brokstad KA, Sjursen H,Zambon M, Cox RJ. Serum IgG titres, but not avidity, correlates with neutralizing antibody response after H5N1 vaccination. Vaccine. 2014;32:4550-7.

36. Huber VC, McKeon RM, Brackin MN, Miller LA, Keating R, Brown SA, Makarova N, Perez DR, Macdonald GH, McCullers JA. Distinct contributions of vaccine- induced immunoglobulin G1 (IgG1) and lgG2a antibodies to protective immunity against influenza. Clin Vaccine Immunol. 2006;13:98190.

37. Kreijtz JH, Bodewes $R$, van Amerongen $G$, Kuiken $T$, Fouchier RA, Osterhaus $A D$, Rimmelzwaan GF. Primary influenza A virus infection induces crossprotective immunity against a lethal infection with a heterosubtypic virus strain in mice. Vaccine. 2007;25:612-20.

38. O'Neill E, Krauss SL, Riberdy JM, Webster RG, Woodland DL. Heterologous protection against lethal A/HongKong/156/97 (H5N1) influenza virus infection in C57BL/6 mice. J Gen Virol. 2001;81:2689-96.

39. Chakir H, Wang H, Lefebvre DE, Webb J, Scott FW. T-bet/GATA-3 ratio as a measure of the Th1/Th2 cytokine profile in mixed cell populations: predominant role of GATA-3. J Immunol Methods. 2003;278:157-69.

40. He YF, Ni TT, Liu ZY, Ye YP, Sun HX. Rapid annotation and structural characterization of saponins in the active fraction of Albizia julibrissin by HPLC coupled with quadrupole time-of-flight mass spectrometry based on accurate mass database. J Sep Sci. 2019;42:2922-2941.

41. Xie Y, Sun HX, Li D. Platycodin D improves the immunogenicity of Newcastle disease virus-based recombinant avian influenza vaccine in mice. Chem Biodiv. 2010;7:677-89.

42. Sun $H X$, Wang $H$, Xu HS, Ni Y. Novel polysaccharide adjuvant from the roots of Actinidia eriantha with dual Th1 and Th2 potentiating activity. Vaccine. 2009;27:3984-91.

43. Sun HX, Zhang J, Chen FY, Chen XF, Zhou ZH, Wang H. Activation of RAW264.7 macrophages by the polysaccharides from the roots of Actinidia eriantha and its Molecular mechanisms. Carbohyd Polym. 2015;121:388-402.

44. Du J, Chen XF, Wang CY, Sun HX. Pathway analysis of global gene expression change in dendritic cells induced by the polysaccharide from the roots of Actinidia eriantha. J Ethnopharmacol. 2018;214:141-52.

\section{Publisher's Note}

Springer Nature remains neutral with regard to jurisdictional claims in published maps and institutional affiliations.

\section{Ready to submit your research? Choose BMC and benefit from}

- fast, convenient online submission

- thorough peer review by experienced researchers in your field

- rapid publication on acceptance

- support for research data, including large and complex data types

- gold Open Access which fosters wider collaboration and increased citations

- maximum visibility for your research: over $100 \mathrm{M}$ website views per year

At BMC, research is always in progress.

Learn more biomedcentral.com/submissions 